REVIEW ARTICLE

\title{
The Imperative for Climate Action to Protect Health
}

\author{
Andy Haines, M.D., and Kristie Ebi, M.P.H., Ph.D.
}

\section{$\checkmark$}

LIMATE CHANGE IS ALREADY ADVERSELY AFFECTING HUMAN HEALTH and health systems, ${ }^{1,2}$ and projected climate change is expected to alter the geographic range and burden of a variety of climate-sensitive health outcomes and to affect the functioning of public health and health care systems. If no additional actions are taken, then over the coming decades, substantial increases in morbidity and mortality are expected in association with a range of health outcomes, including heat-related illnesses, illnesses caused by poor air quality, undernutrition from reduced food quality and security, and selected vectorborne diseases in some locations; at the same time, worker productivity is expected to decrease, particularly at low latitudes. ${ }^{3,4}$ Vulnerable populations and regions will be differentially affected, with expected increases in poverty and inequities as a consequence of climate change. Investments in and policies to promote proactive and effective adaptation and reductions in greenhouse-gas emissions (mitigation) would decrease the magnitude and pattern of health risks, particularly in the medium-to-long term.

OBSERVED AND PROJECTED CLIMATE CHANGE

August 2018 was the 406th straight month during which global mean temperatures were above the long-term mean. ${ }^{5}$ The global mean surface temperature has increased by approximately $1^{\circ} \mathrm{C}$ since preindustrial times, with most of that increase $\left(0.8^{\circ} \mathrm{C}\right)$ occurring since the $1970 \mathrm{~s}$. Atmospheric concentrations of carbon dioxide (the primary greenhouse gas) have risen from approximately $280 \mathrm{ppm}$ in preindustrial times to approximately $410 \mathrm{ppm}$ today. ${ }^{6}$ Carbon dioxide remains in the atmosphere for centuries, with about $20 \%$ persisting for more than 1000 years. Other, short-lived climate pollutants, such as methane and black carbon, also contribute to warming and, in the case of methane, to tropospheric ozone formation. The global mean temperature is currently increasing at a rate of $0.2^{\circ} \mathrm{C}$ per decade (probable range, $0.1^{\circ} \mathrm{C}$ to $0.3^{\circ} \mathrm{C}$ ) owing to past and continuing emissions. ${ }^{7}$ Figure 1 shows the changes in global mean surface temperatures over the period 1850-2017, as compared with the means for the period 1961-1990.

Warmer air can hold more moisture, so increasing temperatures are associated with changes in precipitation patterns. For example, there have been substantial increases in the mean maximum daily precipitation measured in sequential 5-year blocks since 1901 over the eastern United States, with a 27\% increase in the northeastern United States but little change in the western United States. There have also been reductions in soil moisture due to increased temperatures. ${ }^{8}$ Earlier spring melt together with reduced snowpack have been attributed with high con-
From the Departments of Public Health, Environments, and Society and of Population Health, London School of Hygiene and Tropical Medicine, London (A.H.); and the Departments of Global Health and of Environmental and Occupational Health Sciences, University of Washington, Seattle (K.E.). Address reprint requests to Dr. Haines at the Departments of Public Health, Environments, and Society and of Population Health, London School of Hygiene and Tropical Medicine, 15-17 Tavistock PI., London $\mathrm{WClH} 9 \mathrm{SH}$, United Kingdom, or at andy.haines@Ishtm.ac.uk.

N Engl J Med 2019;380:263-73. DOI: 10.1056/NEJMral807873

Copyright (C) 2019 Massachusetts Medical Society. 


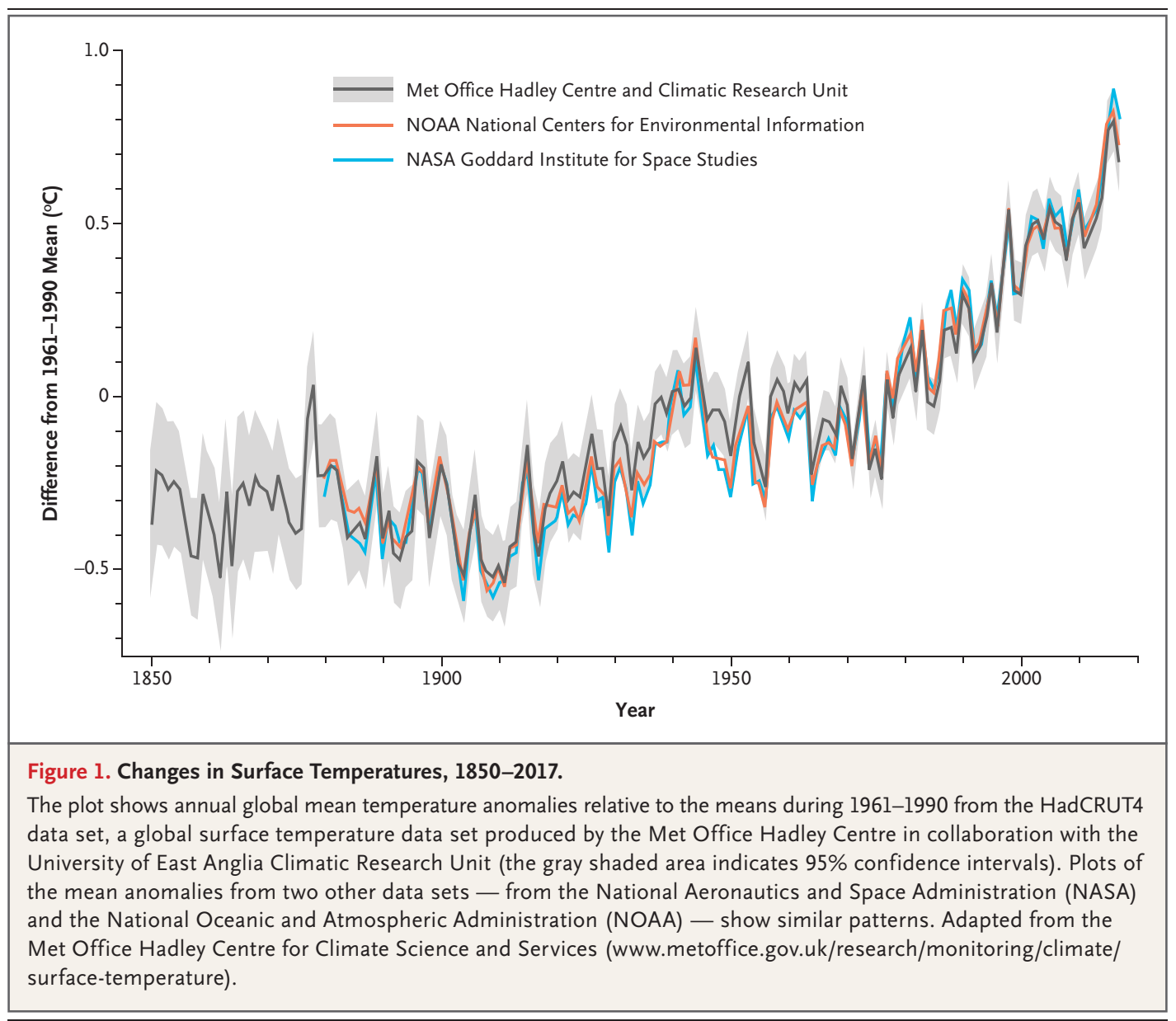

fidence to human-induced climate change in North America, leading to robust projections that, under high-emission scenarios, without changes to water-resource management, prolonged drought is increasingly possible by the end of the century. ${ }^{8}$

A statistical method called detection and attribution is used to identify when a trend in a climate or health variable differs significantly from a defined baseline value and to determine the extent to which the difference in the trend could be attributed to climate change. ${ }^{9}$ Studies in which this method is used show that greenhouse-gas emissions are changing the climate in ways that affect human health. ${ }^{1,2}$ Almost two thirds of the worldwide effects of changes in atmospheric and near-surface ocean temperatures for the period 1971-2010 were attributed to anthropogenic climate change. ${ }^{9}$ Furthermore, it is now possible to determine the role that recent climate change is likely to have played in individual extreme weather and climate events. ${ }^{10}$

The American Meteorological Society undertakes annual assessments of human influences on the climate. Its assessment for the year 2016 showed for the first time that three events would not have happened in the absence of climate change caused by human activities: the record global heat, a high-latitude marine heat wave and its effects on Alaska, and the extreme heat over Asia (the 2015-2016 El Niño contributed to extreme heat over Southeast Asia but not elsewher $\left.\mathrm{e}^{10}\right)$. A detection and attribution study showed that anthropogenic climate change quintupled the risk of extreme vapor-pressure deficits (which in turn increase the likelihood of wildfires) in western North America in June through August of 2016. ${ }^{11}$ In 2016, approximately 3.6 million hectares of land burned in the United States and Canada, and the fires that ravaged California in 


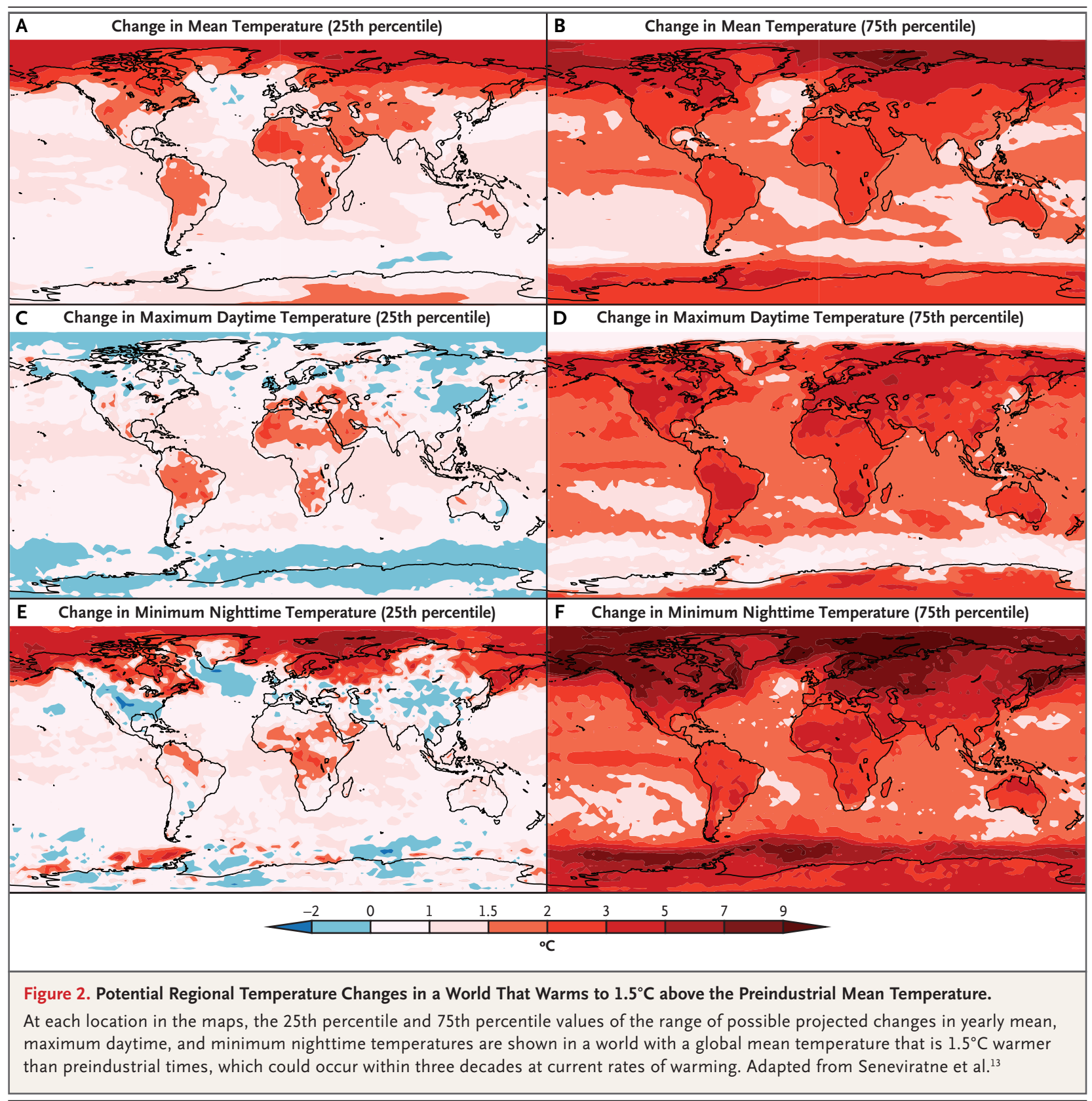

2017 and 2018 were the most destructive wildfires ever recorded in the state. Wildfires can increase daily air-pollution levels by as much as a factor of 10, with adverse effects on health, including an increase in respiratory disease. ${ }^{12}$

Figure 2 shows the range of possible projected changes in mean and yearly maximum daytime temperatures in a world with a global mean temperature that is $1.5^{\circ} \mathrm{C}$ warmer than in preindustrial times, conditions that could occur within three decades at current rates of warming. The substantial differences between the 25th and 75th percentiles of the projections highlight the uncertainties that health systems need to consider when implementing strategies for adaptation. ${ }^{13}$

Greenhouse-gas emissions add energy to the climate system, resulting in increases in the frequency, intensity, and duration of some extreme weather and climate events, including 
heat waves, floods, and droughts, that have important effects on human health. ${ }^{14}$ Under some projections in some regions, toward the end of the century, the coolest day in the summer season may be warmer than the hottest day today. Climate change also causes sea levels to rise; it is projected that an additional 10 million people could be exposed to flooding from a $0.1-\mathrm{m}$ rise in sea level if the mean temperature increase is $2^{\circ} \mathrm{C}$ rather than $1.5^{\circ} \mathrm{C}$. $^{7}$ The sea-level rise could reach several meters if the Antarctic ice sheet becomes unstable or the Greenland ice cap is lost.

The Paris Agreement was a major step forward in global efforts to address climate change, but, even if all signatories honored the commitments, it would not be sufficient to limit warming to $2^{\circ} \mathrm{C}$ above preindustrial levels. Full implementation of the unconditional nationally determined contributions that were agreed on in Paris would be expected to result in a temperature increase of approximately $3.2^{\circ} \mathrm{C}$ by the year 2100 , relative to the preindustrial period. ${ }^{15}$ This underscores the need for urgent action to build on these commitments. The inherent inertia in the climate system means that weather and climate variables will continue to change for several decades after greenhouse-gas emissions have been reduced. ${ }^{14}$ Of particular importance for managing the associated health risks is the fact that warming will be uneven, creating different hazards in different locations. ${ }^{13}$

HEALTH RISKS ASSOCIATED WITH A CHANGING CLIMATE

For more than 20 years, researchers have been investigating the implications of the observed and projected changes in weather and climate for the magnitude and pattern of adverse climatesensitive health outcomes. However, partly because of limited funding, the evidence base remains fragmented and is particularly limited in low-income countries. Figure 3 summarizes the health outcomes that could be affected by climate change (also shown in an interactive graphic, available at NEJM.org). Major pathways through which climate change harms health include direct effects, such as those from increased exposure to high ambient temperatures; effects mediated through natural systems, such as effects on vectorborne diseases; and effects mediated through socioeconomic systems, such as the health consequences of increased impoverishment. The effects of climate change on mental health are increasingly recognized for example, exposure to floods and other extreme events increases the risk of depression and anxiety, which may disproportionately affect people with preexisting mental health problems.

Additional risks continue to be recognized as more is understood about how changing weather patterns can affect the burden of climatesensitive health outcomes. Increasing evidence also indicates that rising carbon dioxide concentrations have adverse effects on the nutritional quality of major cereal crops, such as rice and wheat, including lowering the levels of protein, a range of micronutrients, and $\mathrm{B}$ vitamins. ${ }^{19-21}$ Climate and other environmental changes also reduce the yield of vegetables and legumes overall, which has important implications for the prevention of noncommunicable diseases. ${ }^{22}$

The World Health Organization (WHO) estimated that approximately 250,000 deaths annually between 2030 and 2050 could be due to climate change-related increases in heat exposure in elderly people, as well as increases in diarrheal disease, malaria, dengue, coastal flooding, and childhood stunting. ${ }^{16}$ This is a conservative estimate, because it does not include deaths from other climate-sensitive health outcomes and does not include morbidity or the effects associated with the disruption of health services from extreme weather and climate events. For example, a climate change-associated net increase of 529,000 adult deaths worldwide $(95 \%$ confidence interval [CI], 314,000 to 736,000 ) was projected to result from expected reductions in food availability (particularly fruit and vegetables) by 2050 , as compared with a reference scenario without climate change. ${ }^{23}$ Furthermore, the World Bank estimates that without climate-resilient development (i.e., development that promotes the capacity of societies to absorb climate shocks and evolve effective new coping strategies in response to change), climate change could force more than 100 million people into extreme poverty by $2030 .{ }^{17}$ The risks will be considerably higher without investments in strengthening and expanding current adaptation and mitigation policies, ${ }^{1,3}$ particularly for low-income and marginalized pop- 


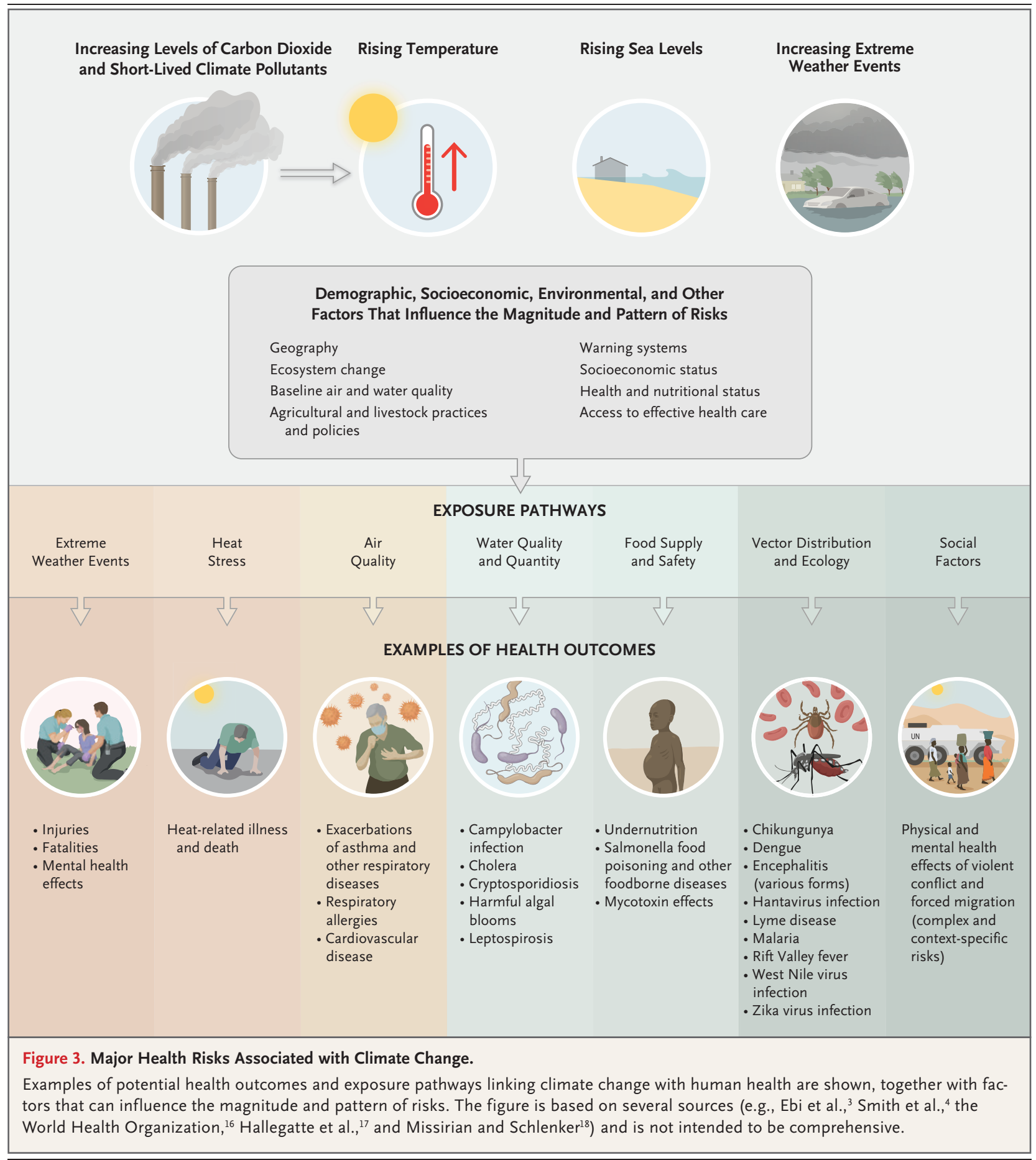

ulations and in low-income countries, which have contributed the least to carbon dioxide emissions.

The magnitude and nature of health risks depend not just on the hazards created by a changing climate but also on the sensitivity of the people, communities, and natural systems that are exposed to those hazards and on the capacity of people, communities, and health systems to prepare for and manage the increasing risks. ${ }^{24}$ For example, in South Asia and East 
Africa, if the population is kept constant at 2015 levels, the number of people exposed to heat that is considered to be severe today could increase by a factor of 4.1 (interdecile range, 2.4 to 9.6) under $1.5^{\circ} \mathrm{C}$ of warming and by a factor of 15.8 (interdecile range, 5.0 to 135 ) under $2^{\circ} \mathrm{C}$ of warming. ${ }^{25}$ Incorporation of the projected population increases substantially exacerbates the exposure risks. In another example, a modeling study using data from 451 locations in 23 countries showed that, in the absence of effective adaptation, net increases in temperature-related excess deaths are projected worldwide under high-emission scenarios. Large net increases in excess mortality could occur between the decade 2010-2019 and the decade 2090-2099 in the highest-emission scenario, ranging on average from $3 \%$ to more than $12 \%$ in hotter regions, such as the central and southern parts of the United States or Europe, and especially Southeast Asia (with inadequate data from Africa). ${ }^{26}$

Increasing heat exposure is expected to progressively reduce labor productivity, particularly in tropical and subtropical regions. A recent study estimated the amount of work lost from heat exposure in three sectors involving different levels of physical activity (service, industry, and agriculture), under an assumption of shaded work conditions. In total, it was estimated that 153 billion hours of labor were lost in 2017 (or 3.4 billion weeks of work) - an increase of 62 billion hours relative to the year 2000 - of which $80 \%$ were in the agricultural sector. ${ }^{27}$ Asylum applications from 103 source countries to the European Union increased nonlinearly when temperatures in the maize-growing season deviated from an optimum of approximately $20^{\circ} \mathrm{C}$, especially at hotter temperatures. ${ }^{18}$ An emissions pathway that peaks in 2040 and then declines was associated with an estimated $28 \%$ increase in asylum applications, whereas a high-emission pathway was associated with a $175 \%$ increase by the end of the century, equivalent to an additional 660,000 asylum applications annually, when other factors are held constant. ${ }^{18}$

Possible pathways of future development, termed the "shared socioeconomic pathways," are increasingly used to identify opportunities and challenges for transitioning to a more resilient and sustainable world. Table 1 shows how the building blocks of climate-resilient health systems could differ across three of these path- ways. ${ }^{29}$ These differences have important consequences for the magnitude and pattern of exposure to climate-related hazards and for the extent of population vulnerability. For example, development sustained by the burning of fossil fuels is expected to lead to high burdens of climate-sensitive preventable outcomes, as well as large numbers of deaths from air pollution, as compared with development powered by clean, renewable energy. ${ }^{28}$

ADAPTATION GAP

The current policies and measures for the management of climate-sensitive health outcomes were not developed in light of climate-change considerations, which means that they need modification to be effective over coming decades. Some examples include the need to enhance surveillance, change the timing and location of specific vector-control measures, and adapt building codes and building locations (including locations of some health care facilities) to address rising temperatures and the risk of flooding. Opportunities exist to capitalize on environmental data to develop early warning and response systems that can provide critical time to deploy proactive measures to reduce the numbers of cases of climate-sensitive health outcomes, such as those for heat waves ${ }^{30}$ and dengue. ${ }^{31}$ Increasing awareness by health care professionals of the health risks associated with climate change is critical for identifying when new diseases appear in a region. Conducting assessments of vulnerability and adaptation at local and national levels is often a first step in identifying the challenges to and opportunities for managing the health risks related to climate change. ${ }^{32}$ Because the climate will continue to change for decades, centuries, and even millennia, iterative riskmanagement approaches are needed to address evolving health risks. Risks cannot be completely averted even with adaptation, and the failure to limit temperature increases makes it more likely that limits to adaptation will be reached in some regions - for example, as a result of exposure to extreme heat or rises in sea level.

Many approaches for increasing preparedness to manage the health risks associated with climate change lie outside the health sector. ${ }^{33}$ Ensuring water and food security, for example, re- 


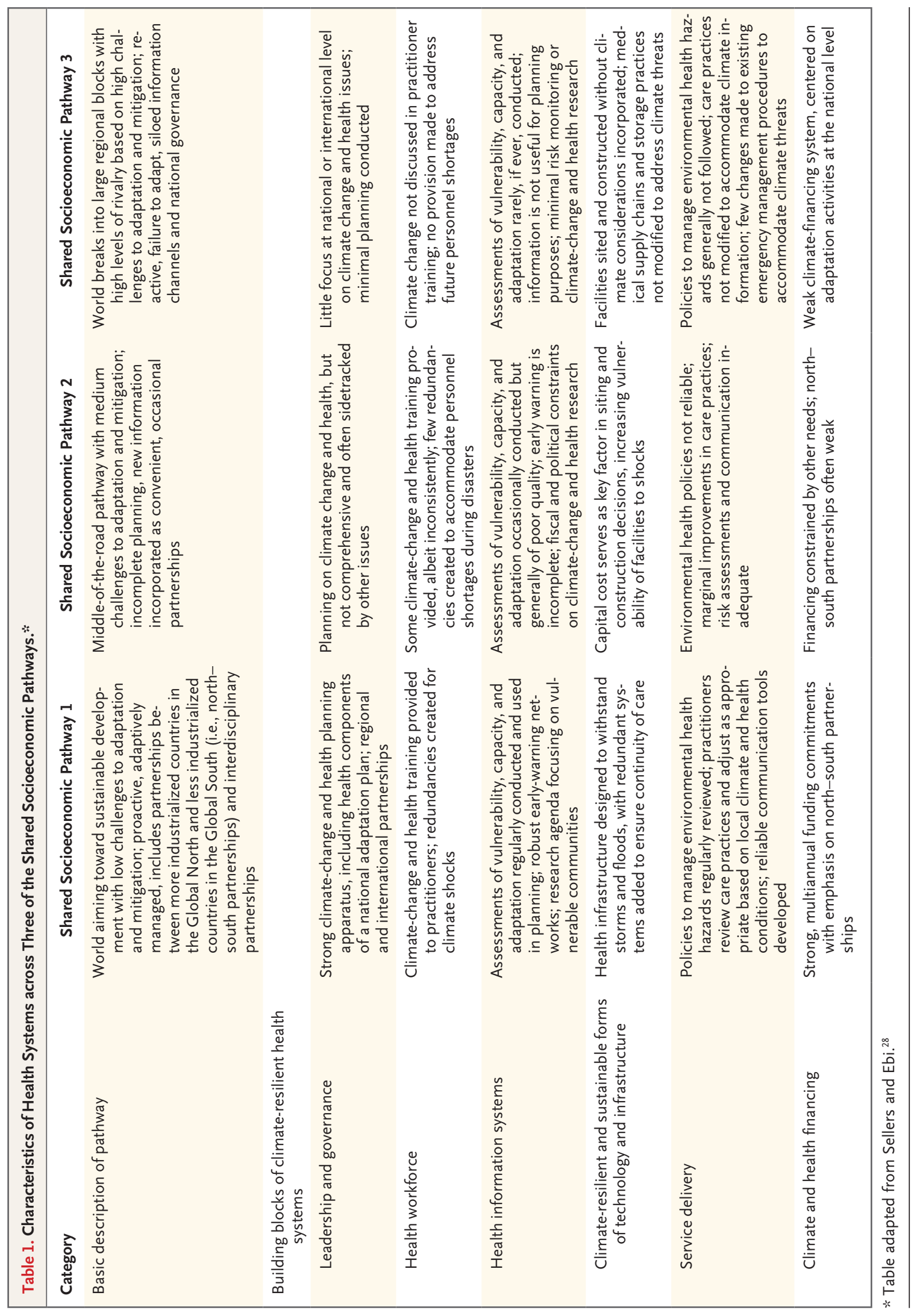


quires collaboration between the health sector and relevant ministries and departments, ensuring that the adaptations they implement promote health and avoid unintended adverse consequences.

HEALTH BENEFITS OF A

“ZERO-CARBON" ECONOMY

One barrier to achieving rapid reductions in carbon dioxide levels and short-lived climate pollutant emissions (including methane, black carbon, and hydrofluorocarbons) is the perception that it is difficult and costly to decarbonize the economy. However, transition to a zero-carbon economy could bring a range of near-term benefits, particularly health benefits, ${ }^{34}$ that could provide an additional impetus for action.

Policies to reduce greenhouse-gas emissions in the energy sector, housing, and the built environment more generally (ranging from buildings to parks); transportation; and agriculture and food systems can result in near-term ancillary benefits to human health. These benefits can arise from reduced exposure to air pollution, particularly fine particulates (particulate matter with a diameter of $\leq 2.5 \mu \mathrm{m}\left[\mathrm{PM}_{2.5}\right]$, including black carbon) and tropospheric ozone (levels of which may increase during climate change, depending partly on trends in ozone precursors $\left.{ }^{4}\right) .{ }^{34}$

Worldwide, ambient air pollution and household air pollution are estimated to be responsible for approximately 6.5 million premature deaths annually. ${ }^{35}$ Recent analyses suggest even higher numbers - nearly 9 million deaths annually associated with the present levels of ambient fine particulate air pollution ${ }^{36}$ and more than 1 million deaths associated with tropospheric ozone, ${ }^{37}$ with increased mortality even when pollution levels are lower than those required by current air-quality standards..$^{38}$ The predominant sources of ambient air pollution vary according to country. For example, in the United States, it is estimated that approximately $58 \%$ of the excess deaths are attributable to the use of fossil fuel and arise particularly from traffic, power production, and industry. ${ }^{39}$ In India, where the use of solid biofuel for residential heating and cooking is widespread, approximately $26 \%$ of excess deaths are due to fossil-fuel use, but this percentage is likely to rise in the future with the escalating demand for energy and increased domestic use of clean fuels. Strategies to provide universal access to clean, zero-carbon energy have great potential to reduce this death toll while also reducing the risks associated with dangerous climate change.

There is a growing literature in which the health benefits of reductions in air pollution as a result of climate-change mitigation strategies are quantified. ${ }^{40}$ For example, one study suggested that mitigation of global greenhouse gases could result in approximately 1.3 million fewer premature deaths in 2050, under a scenario of moderate greenhouse-gas emissions and intermediate economic development and population growth. ${ }^{41}$ When high and low estimates for the value of a life saved (in U.S. dollars) are used and the marginal costs of reducing greenhouse-gas emissions are taken into consideration, the economic benefits arising from reduced air pollution range from $\$ 50$ to $\$ 380$ per ton of carbon dioxide worldwide and from $\$ 30$ to $\$ 600$ per ton in the United States. A comparison of the valuation of health benefits with the mitigation costs of achieving the Paris Agreement targets $\left(2^{\circ} \mathrm{C}\right.$ and $1.5^{\circ} \mathrm{C}$ ) showed that for all future scenarios, the cost of implementing mitigation policies at a global level could be offset by the value of the benefits to health. ${ }^{42}$ In East Asia, the value of the health benefits was estimated to be 10 to 70 times the marginal cost in 2030, but even in developed economies such as the European Union and the United States, the benefits could be substantial. Another study of U.S. mitigation policies that are consistent with the $2^{\circ} \mathrm{C}$ Paris Agreement target suggested that by 2030, clean-energy policies could reduce particulate matter and ozone levels appreciably, thus preventing approximately 175,000 premature deaths, with 22,000 fewer deaths $(95 \% \mathrm{CI}, 11,000$ to 96,000$)$ annually thereafter. Clean transportation could prevent 120,000 premature deaths and 14,000 deaths (95\% CI, 9000 to 52,000) annually thereafter. ${ }^{43}$ Although natural gas results in lower emissions of carbon dioxide and fine particulates than coal, associated methane leaks, which are common, contribute to warming and to tropospheric ozone. Adverse health outcomes such as low birth weight have been linked to proximity to hydraulic fracturing sites, ${ }^{44}$ but the effects are still uncertain and warrant further investigation. 
Interventions in urban environments also provide important opportunities for shared benefits of health and environmental sustainability. Increasing walking and cycling and the use of public transportation and low-emission vehicles can reduce greenhouse-gas emissions and improve health by decreasing the risk of noncommunicable disease through reduced air pollution and increased physical activity, potentially averting costs to the health system. ${ }^{45-47}$

The food system is a major driver of land-use change, demands for fresh water, and greenhouse-gas emissions. A meta-analysis of data from more than 38,000 farms worldwide producing 40 different agricultural goods showed considerable diversity in the environmental effects of similar products (varying by a factor as high as 50), which illustrates the potential for mitigation actions. ${ }^{48}$ In general, the environmental effects of animal-source foods are higher than those of plant-based foods. A systematic review showed that by shifting present dietary intakes to environmentally more sustainable healthy diets, greenhouse-gas emissions could be reduced by a median of 20 to $30 \%$ in high-income areas and reductions in water and land use could also be achieved. ${ }^{49}$ Reductions in environmental effects were generally proportional to the magnitude of the reduction in animal-based food. Dietary changes were projected to modestly reduce allcause mortality in high-income countries ${ }^{50}$; this projection is largely based on the inverse association observed between the consumption of fruit and vegetables and the risks of ischemic heart disease, stroke, and some types of cancers.

Although the health benefits of policies to reduce carbon emissions are potentially large, there may be unintended adverse consequences. ${ }^{34,46}$ An example is the introduction of diesel engines, which are sometimes promoted to reduce greenhouse-gas emissions but have been found to release more fine particulates and nitrogen oxides than gasoline engines. Poorly designed food and agricultural policies to reduce greenhouse-gas emissions could threaten food security by limiting protein sources and increasing food prices for the poor. ${ }^{51}$ In addition, increased exposure to household air pollution could result from improving the energy efficiency of households through the use of insulation and draft proofing without improving ventilation. ${ }^{34}$
Policies must be developed with these potential harmful effects taken into consideration and minimized.

Currently, societies do not pay the full economic costs of burning fossil fuels. Prices of fossil fuels do not incorporate the environmental and health costs of damages associated with rising carbon dioxide levels and exposure to, for example, sulfur dioxide and fine particulate matter; these are considered "externalities." Although a discussion of economic policies for mitigation would be beyond the scope of this review, reflecting these costs in the prices of fossil fuels through appropriate carbon pricing could yield additional revenues ${ }^{52}$ and substantially reduce carbon dioxide emissions and deaths from air pollution. Effective implementation requires well-designed subsidy reform, regulation, and standards, including payments for low-income groups to compensate for losses associated with tax-related price increases. Well-designed policies for the mitigation of climate change can also contribute to the achievement of many of the United Nations Sustainable Development Goals. $^{53}$

\section{CONCLUSIONS}

Climate change is causing injuries, illnesses, and deaths, with the risks projected to increase substantially with additional climate change, threatening the health of many millions of people if there are not rapid increases in investments in adaptation and mitigation. The recent Intergovernmental Panel on Climate Change report $^{7}$ makes a powerful case for "rapid and farreaching" transitions in land, energy, industry, buildings, transportation, and cities, with the aim of limiting global warming to $1.5^{\circ} \mathrm{C}$ by reducing global net human-related emissions of carbon dioxide by approximately 45\% from 2010 levels by 2030. This would reduce the risks of exceeding critical thresholds damaging to natural systems and human societies while providing more time for adaptation.

Health professionals have leading roles to play in addressing climate change. They can support health systems in developing effective adaptation to reduce the health risks of climate change, promote healthy behaviors and policies with low environmental impact, support intersectoral ac- 
tion to reduce the environmental footprint of society in general and the health care system specifically, and undertake research and education on climate change and health. ${ }^{54}$ The pervasive threats to health posed by climate change demand decisive actions from health professionals and governments to protect the health of current and future generations.

Disclosure forms provided by the authors are available with the full text of this article at NEJM.org.
REFERENCES

1. Ebi KL, Ogden NH, Semenza JC, Woodward A. Detecting and attributing health burdens to climate change. Environ Health Perspect 2017;125:085004.

2. Mitchell D, Heaviside C, Vardoulakis $S$, et al. Attributing human mortality during extreme heat waves to anthropogenic climate change. Environ Res Lett 2016;11: 074006.

3. Ebi KL, Hasegawa T, Hayes K, Monaghan A, Paz S, Berry P. Health risks of warming of $1.5^{\circ} \mathrm{C}, 2^{\circ} \mathrm{C}$, and higher, above pre-industrial temperatures. Environ Res Lett 2018;13:063007.

4. Smith KR, Woodward A, CampbellLendrum C, et al. Human health: impacts, adaptation, and co-benefits. In: Field CB, Barros VR, Dokken DJ, Mach KJ, Mastrandrea MD, Bilir TE, eds. Climate change 2014: impacts, adaptation, and vulnerability. Part A: global and sectoral aspects - contribution of Working Group II to the Fifth Assessment Report of the Intergovernmental Panel on Climate Change. Cambridge, United Kingdom: Cambridge University Press, 2014:709-54.

5. Global climate report - April 2018. Washington, DC: National Centers for Environmental Information, 2018 (https:// www.ncdc.noaa.gov/sotc/global/201804). 6. Mauna Loa Observatory home page. Boulder, CO: National Oceanic and Atmospheric Administration Earth System Research Laboratory Global Monitoring Division (https://www.esrl.noaa.gov/gmd/ obop/mlo/).

7. Intergovernmental Panel on Climate Change. Special report: global warming of $1.5^{\circ} \mathrm{C}$ : summary for policymakers. Geneva: World Meteorological Organization, 2018 (https://www.ipcc.ch/sr15/chapter/ summary-for-policy-makers/).

8. Climate science special report: Fourth national climate assessment. Vol. I. Washington, DC: U.S. Global Change Research Program, 2017.

9. Hansen G, Stone D, Auffhammer M, Huggel C, Cramer W. Linking local impacts to changes in climate: a guide to attribution. Reg Environ Change 2016;16: 527-41.

10. Herring SC, Christidis N, Hoell A, Kossin JP, Schreck CJ III, Stott PA. Explaining extreme events of 2016 from a climate perspective. Bull Am Meteorol Soc 2018;99:Suppl:S1-S157.

11. Tett S, Falk A, Rogers M, et al. Anthropogenic forcings and associated changes in fire risk in Western North America and
Australia during 2015/2016. In: Herring SC, Christidis N, Hoell A, Kossin JP, Schreck CJ III, Stott PA. Explaining extreme events of 2016 from a climate perspective. Bull Am Meteorol Soc 2018;99 Suppl:S60-S64.

12. Liu JC, Mickley LJ, Sulprizio MP, et al. Particulate air pollution from wildfires in the Western US under climate change. Clim Change 2016;138:655-66.

13. Seneviratne SI, Rogelj J, Séférian R, et al. The many possible climates from the Paris Agreement's aim of $1.5^{\circ} \mathrm{C}$ warming. Nature 2018;558:41-9.

14. Summary for policymakers. In: Stocker TF, Qin D, Plattner G-K, et al., eds. Climate change 2013: the physical science basis - contribution of Working Group to the Fifth Assessment Report of the Intergovernmental Panel on Climate Change. Cambridge, United Kingdom: Cambridge University Press, 2013.

15. Emissions gap report 2017. Nairobi, Kenya: United Nations Environment Programme, 2017.

16. Quantitative risk assessment of the effects of climate change on selected causes of death, 2030s and 2050s. Geneva: World Health Organization, 2014 (http:/ www.who.int/iris/handle/10665/134014).

17. Hallegatte S, Bangalore $M$, Bonzanigo $\mathrm{L}$, et al. Shock waves: managing the impacts of climate change on poverty. Washington, DC: World Bank, 2015.

18. Missirian A, Schlenker W. Asylum applications respond to temperature fluctuations. Science 2017;358:1610-4.

19. Loladze I. Hidden shift of the ionome of plants exposed to elevated $\mathrm{CO}_{2}$ depletes minerals at the base of human nutrition. Elife 2014;3:e02245.

20. Myers SS, Zanobetti A, Kloog I, et al. Increasing $\mathrm{CO} 2$ threatens human nutrition. Nature 2014;510:139-42.

21. Zhu C, Kobayashi K, Loladze I, et al. Carbon dioxide $\left(\mathrm{CO}_{2}\right)$ levels this century will alter the protein, micronutrients, and vitamin content of rice grains with potential health consequences for the poorest rice-dependent countries. Sci Adv 2018; 4(5):eaaq1012.

22. Scheelbeek PFD, Bird FA, Tuomisto $\mathrm{HL}$, et al. Effect of environmental changes on vegetable and legume yields and nutritional quality. Proc Natl Acad Sci USA 2018;115:6804-9.

23. Springmann M, Mason-D'Croz D, Robinson S, et al. Global and regional health effects of future food production under climate change: a modelling study. Lancet 2016;387:1937-46.

24. Field CB, Barros V, Stocker TF, et al., eds. Managing the risks of extreme events and disasters to advance climate change adaptation: a special report of Working Groups I and II of the Intergovernmental Panel on Climate Change. Cambridge, United Kingdom: Cambridge University Press, 2012.

25. Harrington LJ, Otto FE. Changing population dynamics and uneven temperature emergence combine to exacerbate regional exposure to heat extremes under $1.5^{\circ} \mathrm{C}$ and $2{ }^{\circ} \mathrm{C}$ of warming. Environ Res Lett 2018;13:034011.

26. Gasparrini A, Guo Y, Sera F, et al. Projections of temperature-related excess mortality under climate change scenarios. Lancet Planet Health 2017;1(9):e360-e367. 27. Watts N, Amann M, Arnell N, et al. The 2018 report of the Lancet Countdown on health and climate change: shaping the health of nations for centuries to come. Lancet 2018;392:2479-514.

28. Sellers S, Ebi KL. Climate change and health under the Shared Socioeconomic Pathway framework. Int J Environ Res Public Health 2017;15:3.

29. O'Neill BC, Kriegler E, Ebi KL, et al. The roads ahead: narratives for shared socioeconomic pathways describing world futures in the 21st century. Glob Environ Change 2017;42:169-80.

30. Ebi KL, Teisberg TJ, Kalkstein LS, Robinson L, Weiher RF. Heat watch/warning systems save lives: estimated costs and benefits for Philadelphia 1995-98. Bull Am Meteorol Soc 2004;85:1067-74. 31. Lowe R, Stewart-Ibarra AM, Petrova D, et al. Climate services for health: predicting the evolution of the 2016 dengue season in Machala, Ecuador. Lancet Planet Health 2017;1(4):e142-e151.

32. Ebi KL, Kovats RS, Menne B. An approach for assessing human health vulnerability and public health interventions to adapt to climate change. Environ Health Perspect 2006;114:1930-4.

33. Bowen KJ, Ebi KL. Governing the health risks of climate change: towards multi-sector responses. Curr Opin Environ Sustain 2015;12:80-5.

34. Haines A, McMichael AJ, Smith KR, et al. Public health benefits of strategies to reduce greenhouse-gas emissions: overview and implications for policy makers. Lancet 2009;374:2104-14.

35. Landrigan PJ, Fuller R, Acosta NJR, 
et al. The Lancet Commission on pollution and health. Lancet 2018;391:462512.

36. Burnett R, Chen H, Szyszkowicz M, et al. Global estimates of mortality associated with long-term exposure to outdoor fine particulate matter. Proc Natl Acad Sci U S A 2018;115:9592-7.

37. Malley CS, Henze DK, Kuylenstiern JCI, et al. Updated global estimates of respiratory mortality in adults $\geq 30$ years of age attributable to long-term ozone exposure. Environ Health Perspect 2017;125: 087021.

38. Di Q, Wang Y, Zanobetti A, et al. Air pollution and mortality in the Medicare population. N Engl J Med 2017;376:251322.

39. Lelieveld J, Haines A, Pozzer A. Agedependent health risk from ambient air pollution: a modelling and data analysis of childhood mortality in middle-income and low-income countries. Lancet Planet Health 2018;2(7):e292-e300.

40. Chang KM, Hess JJ, Balbus JM, et al. Ancillary health effects of climate mitigation scenarios as drivers of policy uptake: a review of air quality, transportation and diet co-benefits modeling studies. Environ Res Lett 2017;12:113001.

41. West JJ, Smith SJ, Silva RA, et al. Co- benefits of global greenhouse gas mitigation for future air quality and human health. Nat Clim Chang 2013;3:885-9.

42. Markandya A, Sampedro J, Smith SJ, et al. Health co-benefits from air pollution and mitigation costs of the Paris Agreement: a modelling study. Lancet Planet Health 2018;2(3):e126-e133.

43. Shindell DT, Lee Y, Faluvegi G. Climate and health impacts of US emissions reductions consistent with $2{ }^{\circ} \mathrm{C}$. Nat Clim Chang 2016;6:503-7.

44. Currie J, Greenstone M, Meckel K. Hydraulic fracturing and infant health: new evidence from Pennsylvania. Sci Adv 2017; 3(12):e1603021.

45. Woodcock J, Edwards P, Tonne C, et al. Public health benefits of strategies to reduce greenhouse-gas emissions: urban land transport. Lancet 2009;374:1930-43. 46. Jarrett J, Woodcock J, Griffiths UK, et al. Effect of increasing active travel in urban England and Wales on costs to the National Health Service. Lancet 2012;379: 2198-205.

47. Grabow ML, Spak SN, Holloway T, Stone B Jr, Mednick AC, Patz JA. Air quality and exercise-related health benefits from reduced car travel in the midwestern United States. Environ Health Perspect 2012;120:68-76.
48. Poore J, Nemecek T. Reducing food's environmental impacts through producers and consumers. Science 2018;360:987-92.

49. Aleksandrowicz L, Green R, Joy EJ, Smith P, Haines A. The impacts of dietary change on greenhouse gas emissions, land use, water use, and health: a systematic review. PLoS One 2016;11(11):e0165797.

50. Milner J, Green R, Dangour AD, et al. Health effects of adopting low greenhouse gas emission diets in the UK. BMJ Open 2015;5(4):e007364.

51. Hasegawa T, Fujimori S, Havlík P, et al. Risk of increased food insecurity under stringent global climate change mitigation policy. Nat Clim Chang 2018;8:699-703.

52. Parry IW, Heine MD, Lis E, Li S. Getting energy prices right: from principle to practice. Washington, DC: International Monetary Fund, 2014.

53. Haines A, Amann M, Borgford-Parnell N, Leonard S, Kuylenstierna J, Shindell D. Short-lived climate pollutant mitigation and the Sustainable Development Goals. Nat Clim Chang 2017;7:863-9.

54. Xie E, de Barros EF, Abelsohn A, Stein AT, Haines A. Challenges and opportunities in planetary health for primary care providers. Lancet Planet Health 2018;2(5): e185-e187.

Copyright @ 2019 Massachusetts Medical Society.

IMAGES IN CLINICAL MEDICINE

The Journal welcomes consideration of new submissions for Images in Clinical Medicine. Instructions for authors and procedures for submissions can be found on the Journal's website at NEJM.org. At the discretion of the editor, images that are accepted for publication may appear in the print version of the Journal, the electronic version, or both. 